\title{
Microbial composition, diversity, and activity varies across different types of basal ice
}

44 45
aDepartment of Oceanography, Texas A\&M University, College Station, TX, USA.

bDepartment of Microbiology and Cell Science, University of Florida, Gainesville, FL, USA.

\author{
Shawn M. Doyle ${ }^{a}$ and Brent C. Christner ${ }^{b}$
}

Running title: Microbial ecology of different basal ice types

Abstract word count: 214

Main text word count: 6579

*Corresponding author:

Shawn M. Doyle

Department of Oceanography

Texas A\&M University

Eller O\&M Bldg, Rm 716D

College Station, TX, 77843-3146

Tel: 979-845-5105

E-mail: shawndoyle@tamu.edu

Competing Interests: The authors declare no competing financial interests. 
ABSTRACT

Basal ice often contains entrained subglacial debris and sediment which can serve

as a source of nutrients and organic matter and provide habitat for microorganisms

adapted to frozen conditions. However, basal ice comes in many different forms and

comparatively little is known about how microbial composition, diversity, and activity vary

51 across different types of basal ice. Here, we investigated these parameters in four different

52 types of basal ice from two different glaciers and then used a meta-analysis to compare our

53 findings with microbiome studies of other permanently frozen environments. We found

54 microbiome composition varies substantially between basal ice types, even within the same glacier. Further, the microbiomes of sediment-rich basal ices were distinct from those

56 found in glacial ice and instead were most like those found in permafrost. Consistent with

57 this, microbial diversity was also comparable to that found in permafrost and was much

58 higher relative to glacial ice. Patterns of $16 \mathrm{~S}$ rRNA read abundance from RNA relative to

59 DNA implicated certain taxa as potentially active in basal ice with ice temperature

60 appearing to be an important predictor for the diversity of taxa inferred to be active. Our

61 results improve our understanding of the microbial ecology of different basal ice types and

62 provide insight into which types are likely habitats for metabolizing microbial

63 communities.

64

65

66

67

68 


\section{INTRODUCTION}

Basal ice has a chemistry and physical structure that is directly affected by its

71 proximity to and interaction with material beneath the glacier (Knight, 1997). Basal ice

72 layers are typically entrained with debris from the underlying substrate that ranges in size

73 from fine-grained clays and silts to coarse sands, gravels, and boulders. Basal ice formation

74 can produce layering and stratification patterns that become deformed by the folding and

75 shearing forces associated with glacier flow. These processes of entraining and

76 restructuring of subglacial debris combine to produce various types of basal ice. This

77 ranges from relatively debris-poor types containing $<1 \%(\mathrm{w} / \mathrm{v})$ sediment to debris-rich

78 types composed almost entirely of sediment with only interstitial ice (Knight, 1997). When

79 compared to overlying englacial ice (i.e., derived from snowfall and deposited aerosols), the sediment-rich basal ice contains higher concentrations of microbial substrates such as

81 formate, acetate, ferrous iron, and ammonia (Skidmore et al., 2000; Wadham et al., 2004;

82 Tung et al., 2006; Yde et al., 2010). These compounds are hypothesized to be an important

83 source of electron donors for heterotrophic and lithotrophic microorganisms entrapped in

84 subglacial environments, including the basal ice itself (Montross et al., 2013, 2014).

85 Before there was much interest in the microbiology of the cryosphere, basal ice

86 microbial communities were assumed to exist in a persistent state of metabolic dormancy

87 while frozen. This view began to change around the turn of the century after mounting

88 evidence from several pioneering studies revealed microorganisms are not only abundant

89 in subglacial environments but actively participate in weathering processes (Sharp et al.,

90 1999; Skidmore et al., 2000; Tranter et al., 2002, 2005; Sheridan et al., 2003; Miteva et al.,

91 2004; Yung et al., 2007). The metabolic activity of basal ice microorganisms is now thought 
92 to play an important role not only in the biogeochemistry of basal ice but also downstream

93 terrestrial, freshwater, and marine environments which receive seasonal discharges of

94 basal meltwater (Wadham et al., 2010; Barker et al., 2018; Hopwood et al., 2019; Vick-

95 Majors et al., 2020). Indeed, basal meltwater is one of the largest sources of labile dissolved

96 organic carbon and iron to coastal oceans adjacent to glaciated watersheds (Hood et al.,

97 2009; Bhatia et al., 2013).

Due to accelerated rates of melt in many regions, basal ice microorganisms may also

99 play an important role in global carbon cycling. The Greenland and Antarctic Ice sheets

100 alone are estimated to contain $\sim 10.2$ Pg of organic carbon (Priscu et al., 2008), $\sim 0.5 \%$ of

101 the estimated world's total soil organic carbon pool (Batjes, 2014). The subglacial

102 production of biogenic methane and its subsequent release during periods of ice sheet

103 retreat could represent a positive feedback mechanism that accelerates further climate

104 warming (Wadham et al., 2012). Indeed, basal ice sediments from John Evans Glacier

105 (Skidmore et al., 2000) and Robertson Glacier (Boyd et al., 2010) have been found to

106 contain viable methanogens and methanotrophy has been documented in subglacial water

107 from the Greenland (Dieser et al., 2014) and Antarctic ice sheets (Michaud et al., 2017).

108 Microbial activities in the subglacial and basal ice zones of the world's glaciers and ice

109 sheets may thus be an overlooked component of Earth's climate oscillations over geologic

110 timeframes. Despite this potential importance, accessing the basal zone of glaciers is

111 logistically difficult and our understanding of basal ice microorganisms and how their

112 composition and activity varies between different types of basal ice is still limited.

In this study, we used $16 \mathrm{~S}$ rRNA gene amplicon sequencing to profile the

114 composition and structure of microbial assemblages within several different basal ices and 
115 RNA-based approaches to identify potentially active taxa. To explore how these microbial

116 assemblages compare to those in other permanently frozen environments, we performed a

117 meta-analysis that combined our data with that from other studies. Many of these studies

118 sequenced different variable regions of the $16 \mathrm{~S}$ rRNA gene (e.g. V4, V2, V3V4) that do not

119 fully overlap, hindering the use of traditional OTU-based approaches. To address this, we

120 used the SATé-enabled phylogenetic placement (SEPP) technique to insert exact amplicon

121 sequence variants (ASVs) from these heterogenous variable regions into the same

122 reference phylogeny (Janssen et al., 2018). This enabled a phylogenetically stable

123 comparison of the microbial assemblages inhabiting these different frozen environments.

124 In contrast to the aeolian-source microbes in englacial ice, the microorganisms in basal ice

125 appear to represent "communities" in an ecological sense. We discuss the implications of

126 microbial processes in an important transient environment of the cryosphere.

\section{METHODS AND MATERIALS}

2.1 Ice sampling

Taylor Glacier

Taylor Glacier is an outlet glacier of the East Antarctic Ice Sheet that terminates at

132 the western end of Taylor Valley (McMurdo Dry Valleys, Victoria Land, Antarctica). During

133 the austral summers of 2007 and 2009, two subglacial tunnels were excavated into the

134 basal zone of the northern lateral margin of the glacier (Figure S1). The tunnels were

135 initiated on fresh ice aprons and extended $\sim 8 \mathrm{~m}$ in from the glacier face. At the end of each

136 tunnel, a vertical shaft (2007 expedition) or large chamber (2009 expedition) was

137 excavated to expose a stratigraphic sequence of multiple basal ice types (Montross et al. 
2014). Electric chainsaws equipped with unlubricated carbide tipped chains were used to collect samples of the ice sequence from each basal ice type. Ice samples were wrapped in

140 plastic, packed into insulated containers, and shipped frozen to Louisiana State University

141 where they were subsequently stored at $-20{ }^{\circ} \mathrm{C}$.

142 Matanuska Glacier

144 approximately $140 \mathrm{~km}$ northeast of Anchorage. In July 2013, a horizon of debris-rich basal

145 ice exposed near the glacier terminus was sampled using an electric chainsaw (Figure S2).

146 After collection, the ice samples were packaged in polypropylene flat wrap and shipped

147 frozen to Louisiana State University for storage at $-20^{\circ} \mathrm{C}$.

\subsection{Ice decontamination}

Within a temperature-controlled laboratory $\left(-5^{\circ} \mathrm{C}\right), \sim 2 \mathrm{~kg}$ subsamples were cut from

150 large samples of the basal ice using either a band saw (for the sediment-poor basal ice) or a

151 diamond-bladed masonry saw (sediment-rich basal ice). The surface of the freshly cut

152 samples was then cleaned following previous methods (Christner et al., 2005). Briefly, the

153 outermost surface was physically removed by scraping with an autoclaved microtome

154 blade and the newly exposed ice surface was then washed with chilled $\left(-5^{\circ} \mathrm{C}\right), 0.22 \mu \mathrm{m}$

155 filtered 95\% ethanol. Microtome scraping was omitted when processing sediment-rich

156 samples due to the presence of coarse granules and stones embedded in the sediment-

157 layers. Following the ethanol wash, samples were washed extensively with ice-cold, 0.22

$158 \mu \mathrm{m}$, twice-autoclaved deionized water until a minimum of $\sim 5 \mathrm{~mm}$ of the outer surface had

159 been removed based on the ice weight. Large, sterilized surgical forceps were used to

160 handle all ice samples during decontamination and were exchanged frequently during the 
161 procedure to prevent carryover contamination. Sample weights before and after

162 decontamination were used to estimate the amount of material removed from each sample

163 during processing, which was typically between $15 \%$ and $25 \%$ of the initial mass.

The effectiveness of the decontamination procedure was monitored by coating ice

165 samples beforehand with a tracer solution that consisted of three components: (1) 108

166 cells $\mathrm{mL}^{-1}$ of $E$. coli JM109 cells transformed with a pETBlue-2 plasmid (Novagen)

167 containing the gene for alcohol dehydrogenase (ADH) from Drosophila melanogaster, (2)

168 fluorescein (1000 ppm), and (3) 33\% (v/v) glycerol to prevent freezing on the ice at $-5^{\circ} \mathrm{C}$.

169 The removal of the tracer was monitored after each step of the decontamination procedure

170 (i.e. scraping, ethanol wash, $\mathrm{H}_{2} \mathrm{O}$ wash). The fluorescein fluorophore component was

171 monitored by quantifying blue-green fluorescence in $200 \mu \mathrm{L}$ of rinse-water or meltwater

172 using a BioTurner 20/20n Luminometer (P/N 2030-002) equipped with the blue

173 fluorescence module (BioTurner 2030-041). The pETBlue-2 plasmid component was

174 monitored using a PCR with the following conditions: $1 \mathrm{U}$ of Taq DNA polymerase

175 (5PRIME), $1 \times$ MasterTaq buffer, $1 \times$ TaqMaster PCR enhancer, $1.5 \mathrm{mM} \mathrm{Mg}{ }^{2+}, 0.2 \mu \mathrm{M}$ of each

176 primer (TF7: 5'-TAATACGACTCACTATAGGG -3'; pETBlue-DOWN: 5'-

177 GTTAAATTGCTAACGCAGTCA-3'), $200 \mu \mathrm{M}$ dNTPs, and 100 pg of template DNA. Thirty

178 cycles of PCR were done with a 30 s denaturation step at $94{ }^{\circ} \mathrm{C}, 60$ s annealing step at $55{ }^{\circ} \mathrm{C}$

179 and extension at $72{ }^{\circ} \mathrm{C}$ for $60 \mathrm{~s}$, followed by a final extension at $72{ }^{\circ} \mathrm{C}$ for $10 \mathrm{~min}$. The

180 presence of viable $E$. coli was monitored by spread plating rinse-water and meltwater on

181 agar-solidified LB media containing ampicillin $\left(100 \mu \mathrm{g} \mathrm{mL}^{-1}\right)$ followed by incubation at 37

$182{ }^{\circ} \mathrm{C}$. Samples in which any component of the tracer solution was detected in the final

183 meltwater were discarded and reprocessed from a new subsample. 


\subsection{ATP analysis}

Immediately after melting, samples were filtered through $0.22 \mu \mathrm{m}$ pore size

polyethersulfone (Supor; Pall) filters using a bench-top vacuum manifold $(\leq 20 \mathrm{kPa})$. Clean

ice samples were filtered through a $25 \mathrm{~mm}$ diameter filter while banded, solid, and

dispersed ice samples were processed through either a $47 \mathrm{~mm}$ or $90 \mathrm{~mm}$ diameter filter, supernatant was collected.

204 addition of luciferase and measurement of luminescence. 
207 prepared fresh for each series of measurements and consisted of $100 \mathrm{U} \mathrm{ml}^{-1}$ luciferase and

$2080.140 \mathrm{mM}$ D-luciferin. Luminescence was quantified with a 20/20n luminometer

209 (Promega) using auto-injection of $100 \mu \mathrm{L}$ of the luciferase-luciferin cocktail. Relative

210 luminescence units (RLU) were integrated for three seconds immediately after injection.

211 Sample RLU values were corrected for adsorption and inhibition using the following

212 formula:

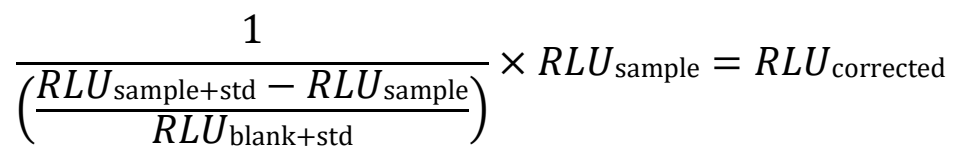

The corrected RLU values were used together with the standard calibration curve to

217 corrected for dilution and normalized to the mass of the ice sampled. All values reported

218 are the means of replicate samples ( $n=3$ to 5$)$.

\subsection{Nucleic acid extraction}

221 melted at $4^{\circ} \mathrm{C}$. For samples from sediment-rich basal ice (i.e. banded, solid, and dispersed

222 ice), DNA was extracted directly from the sediment recovered after melting using MoBio

223 PowerMax DNA Isolation kits. To increase DNA extraction yields, two 10g (wet weight)

224 extractions were combined onto a single silica spin column for each sample. For samples

225 from sediment-poor basal ice (i.e. clean ice), meltwater was filtered onto $47 \mathrm{~mm}, 0.22 \mu \mathrm{m}$

226 pore size Supor PES filter membranes (Pall) with $\leq 20 \mathrm{~cm} \mathrm{Hg}$ of vacuum. DNA was extracted

227 from the filters using MoBio PowerWater DNA Isolation kits as per the manufacturer's

228 instructions with one exception: the mechanical lysis step was performed on a BioSpec 
MiniBeadbeater-8 for 2 minutes at maximum speed. All DNA samples were stored at $-80^{\circ} \mathrm{C}$ until PCR amplification.

Due to the low biomass we expected in the basal ice $\left(\leq 10^{4}\right.$ cells $\mathrm{g}^{-1}$; (Doyle et al.,

232 2013)), very large samples ( $5 \mathrm{~kg}$ of ice) were processed to recover enough RNA for

233 reverse transcription PCR (Table S1). To facilitate filtration of such large sample sizes,

234 coarse sediment was removed from sediment-rich basal ice samples after melting using

235 low speed centrifugation $\left(700 \times \mathrm{g}, 10 \mathrm{~min}, 4^{\circ} \mathrm{C}\right)$. The resulting supernatant containing fine

236 clay and silt-like particles was then concentrated onto $90 \mathrm{~mm}, 0.22 \mu \mathrm{m}$ pore size Supor PES

237 filter membranes. Meltwater from clean ice samples did not require this centrifugation step

238 and were directly filtered onto $90 \mathrm{~mm}, 0.22 \mu \mathrm{m}$ pore size Supor PES filters. After filtration,

239 all filters were immediately processed for RNA extraction using a modified phenol-

240 chloroform extraction protocol (Dieser et al., 2014). Briefly, filters were sliced into small

241 pieces using a sterile scalpel, immersed in $3 \mathrm{~mL}$ of TE buffer (1 mM EDTA, $10 \mathrm{mM}$ Tris; $\mathrm{pH}$

242 6.3) containing lysozyme (15 mg mL-1), and vortexed for 30 minutes at room temperature.

243 Samples were then homogenized in a BioSpec Mini-Beadbeater for 2 minutes at maximum

244 speed using $\sim 1 \mathrm{~g}$ of sterilized $0.1 \mathrm{~mm}$ diameter zirconia/silica beads. After bead beating,

245 crude extracts were amended with two volumes of chilled $\left(4^{\circ} \mathrm{C}\right)$ denaturing buffer $(4 \mathrm{M}$

246 guanidine thiocyanate, $50 \mathrm{mM}$ Tris, $10 \mathrm{mM}$ EDTA, 1\% w/v N-lauroylsarcosine, $1 \% \beta$ -

247 mercaptoethanol), the resulting insoluble material was pelleted via centrifugation (4500×g

248 for $5 \mathrm{~min}$ at $4^{\circ} \mathrm{C}$ ), and the supernatant was collected. The pellet was washed with $3 \mathrm{~mL}$ of

249 chilled denaturing buffer, centrifuged again, and the resulting supernatant pooled with the

250 first. This pooled lysate was then extracted with an equal volume of

251 phenol:chloroform:isoamyl alcohol (25:24:1, $\mathrm{pH} 6.6)$, followed by a second extraction with 
252 chloroform:isoamyl alcohol (24:1). Nucleic acids were purified from these extracts via an

253 overnight ethanol precipitation with $0.3 \mathrm{M}$ sodium acetate ( $\mathrm{pH}$ 6.0). Linear acrylamide (20

$254 \mu \mathrm{g} \mathrm{mL}{ }^{-1}$; Ambion) was used as a coprecipitant to aid recovery. Genomic DNA was

255 eliminated from RNA extracts by digesting for one hour at $37^{\circ} \mathrm{C}$ with $4 \mathrm{U}$ of TURBO DNAase

256 (Ambion) followed by purification with MEGAclear Transcription Clean-Up kits (Ambion).

257 Extracted DNA and RNA concentrations were measured using Quant-it Picogreen and

258 Ribogreen kits (Life Technologies), respectively, per the manufacturer's instructions.

\section{$2.516 S$ rRNA amplicon sequencing}

From the RNA extracted, complementary DNA (cDNA) was reverse transcribed from

$261 \sim 1$ ng of total RNA using SuperScript II reverse transcriptase with the 806R primer (5'-

262 GGACTACVSGGGTATCTAAT-3') following the manufacturer's protocol. Negative control

263 reactions lacking RNA template or reverse transcriptase were conducted to monitor for

264 contaminating RNA and DNA molecules, respectively.

266 DNA extracts and cDNA libraries using a barcoded 515F-806R primer pair (Caporaso et al.,

267 2012). Each $50 \mu \mathrm{L}$ PCR contained 100 pg of DNA or cDNA, 2.5 U of AmpliTaq Gold DNA

268 polymerase LD (Invitrogen), $1 \times$ Gold Buffer, $2.5 \mathrm{mM} \mathrm{MgCl} 2,0.2 \mu \mathrm{M}$ of each primer, and 0.2

$269 \mu \mathrm{M}$ dNTPs. Amplification conditions included at $95^{\circ} \mathrm{C}$ for $9 \mathrm{~min}$, followed by 30 to 40 cycles

270 of denaturation at $94^{\circ} \mathrm{C}$ for $1 \mathrm{~min}$, annealing at $50^{\circ} \mathrm{C}$ for $30 \mathrm{~s}$, and extension at $72^{\circ} \mathrm{C}$ for $30 \mathrm{~s}$.

271 A final extension was performed at $72^{\circ} \mathrm{C}$ for $10 \mathrm{~min}$. Following amplification, amplicons

272 were separated by electrophoresis on a $2 \%$ agarose gel to assess relative band intensity

273 and size. The amplicons were quantified with Quant-it fluorometry and pooled at

274 equimolar concentrations. Two extraction blanks were included in the pooled libraries to 
275 serve as procedural controls (Salter et al., 2014). Pooled libraries were purified with a

276 MoBio UltraClean PCR Cleanup Kit and sequenced on the Illumina MiSeq platform (v2

277 chemistry, 2× 250 bp; Georgia Genomics Facility).

\section{$2.616 S$ rRNA amplicon analysis}

Sequence read curation and processing was performed using DADA2 (Callahan et maxEE=2, R1 truncLen=240, R2 truncLen=200). Error rates for the filtered and trimmed

282 R1 and R2 reads were calculated using the learnErrors function and subsequently used to

283 denoise reads using the DADA2 sample inference algorithm. The denoised reads were

284 merged into amplicon sequence variants (ASV) using a global ends-free alignment. Paired

285 reads containing mismatches in the overlapping region were removed from the dataset.

286 Chimeric ASVs were identified and removed by using the consensus method within the

287 removeBimeraDenovo function. A consensus taxonomy for each ASV was then assigned

288 using a naïve Bayesian classifier (Wang et al., 2007) trained on release 132 of the SILVA

289 reference database (Quast et al., 2013). The dataset was then subsampled to an even read

290 depth across all samples (59,577 sequences). Any ASV classified as a chloroplast,

291 mitochondria, or from which $\geq 0.1 \%$ of its reads were from a procedural blank were

292 removed. Any ASV that was observed exclusively in an RNA library was flagged as a

293 potential contaminant.

\section{$294 \quad 2.7$ Meta-analyses of microbiomes of permanently frozen ecosystems}

295 Publicly available 16S rRNA amplicon datasets from similar permanently frozen

296 environments were identified using a search of the NCBI Sequence Read Archive and

297 downloaded using the SRA Toolbox fastq-dump function. Run tables were aggregated and 
studies based on Sanger sequencing were excluded; only datasets based on Illumina, 454,

300 reads were not demultiplexed before being uploaded to the SRA were also excluded. A list

301 of datasets that met these criteria and were included in the meta-analysis are detailed in

302 Table S2.

304 produce an ASV table. For each study, the filtering parameters were adjusted to account for

305 variation in fragment length and the $16 \mathrm{~S}$ rRNA variable region sequenced. Due to higher

306 rates of homopolymer and indel errors with 454 and IonTorrent sequencing, datasets using

307 these platforms used a band size parameter of 32 and homopolymer region $(\geq 3$ repeated

308 bases) gap cost of -1 during the sample inference algorithm. For Illumina datasets, the band

309 size parameter was set to 16 and gaps in homopolymer regions were treated as normal

310 gaps (gap cost of -8). Nine datasets had to be removed from the meta-analysis after these

311 steps due to the loss of too many sequences during quality control steps within the DADA2

312 pipeline. Complete parameter details and throughput statistics for each dataset in the final

313 meta-analysis are available in Table S3 and S4.

314 ASV sequences from each study were merged and inserted into the 99\% Greengenes

315 reference tree (McDonald et al., 2012) using the SATé-enabled phylogenetic placement

316 (SEPP) technique (Mirarab et al., 2012) within the QIIME2 fragment-insertion plugin

317 (Janssen et al., 2018). The merged ASV tables from each study were filtered to remove ASVs

318 rejected from tree insertion by SEPP. 


\subsection{Data availability}

323 BioProject PRJNA282540.

\section{RESULTS}

\subsection{Description of Basal Ice Samples}

Based on the nomenclature of (Hubbard et al., 2009), we identified three distinct

328 types of basal ice in the basal ice profiles sampled from Taylor Glacier: clean ice, banded

329 ice, and solid ice (Table 1; Figure S3). All three types were collected during the 2007

330 expedition, while only clean ice and banded ice horizons were targeted during the 2009

331 expedition. The basal ice recovered from Matanuska Glacier was identified as dispersed ice

332 and was the only type observed at the location of sampling.

Table 1. Description of basal ice types collected in this study

\begin{tabular}{|c|c|c|c|}
\hline Type & Glacier & Temp $\left({ }^{\circ} \mathrm{C}\right)$ & Description \\
\hline Clean ice & Taylor & -15 & debris-free ice \\
\hline Banded ice & Taylor & -15 & $\begin{array}{l}\text { finely stratified layers of debris and ice, layers } \\
\text { range in thickness from a few } \mathrm{mm} \text { to several } \mathrm{cm}\end{array}$ \\
\hline Solid ice & Taylor & -15 & $\begin{array}{l}\text { composed primarily of frozen debris with only } \\
\text { interstitial ice, no visible layering }\end{array}$ \\
\hline Dispersed ice & Matanuska & $\sim 0$ & $\begin{array}{l}\text { contains scattered debris aggregated into small } \\
\text { clusters, no visible layering }\end{array}$ \\
\hline
\end{tabular}

\subsection{Nucleic acids in sediment-rich and sediment-poor basal ice}

The amount of DNA and RNA extracted from each sample was normalized to sample 
sediment-poor clean ice (Table 2). Between the sediment-rich basal ice types, the

341 more DNA per gram of ice than the banded and solid basal ices from the cold-based $\left(-15^{\circ} \mathrm{C}\right)$

342 Taylor Glacier. RNA concentrations were very low in all basal ice types, with the highest

343 concentration-though only marginally-observed in Matanuska's dispersed basal ice.

Table 2. Cell counts, biomass estimates, and yield of DNA and RNA extracted from basal ice samples. Sediment-rich basal ice facies are highlighted in gray.

\begin{tabular}{|c|c|c|c|c|c|}
\hline \multirow[b]{2}{*}{ Sample } & \multirow{2}{*}{$\begin{array}{l}\text { Cell Counts* } \\
\text { cells g }{ }^{-1} \text { ice } \\
\left(\times 10^{3}\right)\end{array}$} & \multicolumn{2}{|c|}{$\begin{array}{l}\text { Yield (pg g } \\
\text { ice) }\end{array}$} & \multicolumn{2}{|c|}{ Biomass Estimates } \\
\hline & & DNA & RNA & $\begin{array}{l}\text { estimated genomes }{ }^{\dagger} \\
\qquad \mathrm{g}^{-1} \text { ice }\left(\times 10^{3}\right)\end{array}$ & ATP (pg g ${ }^{-1}$ ice $)$ \\
\hline Clean07 & $0.3-0.5$ & 4.7 & 0.7 & 1.9 & $<0.01-0.04$ \\
\hline Clean09 & - & 1.4 & - & 0.6 & - \\
\hline Banded07 & $1.8-18.2$ & 16994.3 & 2.3 & 6797.7 & - \\
\hline Banded09 & - & 16140.1 & 0.8 & 6456.0 & $0.24-2.8$ \\
\hline Solid & 6.7 & 14366.2 & 1.2 & 5746.5 & $<0.01$ \\
\hline Dispersed & - & 98860.2 & 3.2 & 39544.1 & $0.06-0.14$ \\
\hline
\end{tabular}

\subsection{Composition of microbial assemblages in different types of basal ice}

A total of 4,227,678 paired-end reads with an average read length of $253 \mathrm{bp}$ were obtained from MiSeq sequencing. After filtration and denoising, 2,883,221 non-chimeric sequences representing 3310 ASVs remained. Subsampling and culling of ASVs classified as plastids or flagged as potential contaminants produced a final, curated dataset composed of 2021 ASVs. Based on average-neighbor clustering of Bray-Curtis distances, the basal ice samples clustered into three significantly different (AMOVA; F[2,3]=5.23, $p=0.017$ ) groups: 
354 microbial assemblages overwhelmingly composed of Firmicutes (68\%) and Proteobacteria

355 (25\%), with smaller proportions of Bacteroidetes (5\%) and Actinobacteria (1\%). The genus

356 Tumebacillus was especially abundant in the clean ice samples (Figure 1A). Assemblages

357 within the banded and solid ice samples were comparatively more diverse than those

358 found in clean ice (Figure 2), with a wider range of abundant phyla represented:

359 Actinobacteria (26\%), Firmicutes (23\%), Bacteroidetes (19\%), Proteobacteria (11\%),

360 Atribacteria (9\%), Tenericutes (7\%), and Planctomycetes (1\%). Notably, ASVs related to the

361 class Clostridia composed about $20 \%$ of the communities in these samples. Lastly, the

362 microbial assemblage within Matanuska's dispersed basal ice was distinct from those

363 observed from Taylor Glacier. Here we observed significant amounts of Nitrospirae (39\%)

364 and Betaproteobacteria (30\%), of which several of the most abundant ASVs were related to

365 sulfur and/or iron cycling members of the genera Thermodesulfovibrio, Rhodoferax, and

366 Thiobacillus.

367 3.4 Assessing metabolic status of bacterial taxa within different types of basal ice

368 With the RNA libraries, we identified 141 potentially metabolically active ASVs (7\%

369 of total) taxa within the basal ice. Of these ASVs, 80 had RNA/DNA abundance log-ratios $>1$

370 (Table S5) and thus we focused on these as having the highest potential for metabolic

371 activity. The vast majority (63 ASVs) of these taxa were observed in the dispersed ice from

372 Matanuska Glacier (Figure 1B), the warmest and youngest basal ice sampled in this study.

373 Here, many of these ASVs were members of the Chloroflexi or Deltaproteobacteria, with

374 some of the largest RNA/DNA abundance log-ratios belonging to Desulfocapsa, Syntrophus,

375 and unassigned members of the family Anaerolineaceae. Within the banded basal ice from

376 Taylor Glacier, over half of potentially active ASVs instead belonged to the Firmicutes. 
377 Among this phylum, members of the Paenisporosarcina, Paenibacillaceae,

378 Desulfosporosinus, Caldicoprobacter, and Virgibacillus had by far the highest activity

379 potential and represented $>90 \%$ of the RNA reads in these samples. In comparison, the

380 clean and solid basal ice had the least number of potentially active ASVs-10 altogether

381 comprising only 472 RNA reads in total, only 2 of which had RNA/DNA abundance log-

382 ratios $>1$ - suggesting very little to no metabolic activity.

\subsection{Meta-Analysis: Microbial populations of various permanently frozen}

environments

For the meta-analysis, we analyzed 33.6 million 16S rRNA sequences across 146 dataset contained 17.5 million non-chimeric sequences representing 14,114 unique ASVs.

391 between these frozen environments. Of the basal ice assemblages characterized in this

392 study, alpha diversity was higher in sediment-rich basal ice types than in the sediment-

393 poor clean ice $(t(4)=3.34, \mathrm{p}=0.03$ ) (Figure 2 ). Compared to the other frozen environments

394 in this meta-analysis, alpha diversity within our sediment-rich basal ice samples from

395 Antarctica were most similar to that observed in permafrost sampled from the Storflaket

396 peat bog in northern Sweden (Monteux et al., 2018). Conversely, alpha diversity within

397 Taylor Glacier's clean ice was most similar to that found in englacial ice samples from the

398 GISP2D, NEEM, and WAIS Divide ice cores (Buford Price et al., 2015). 
To visualize microbial $\beta$-diversity between samples, we used a hierarchical cluster

400

401

402

403

404

405

406

407

408

409

410

411

412

413

414

415

416

417

418

419

420

421

analysis of weighted UniFrac distances (wUF). Microbial communities largely clustered by the type of permanently frozen environment they inhabited, though some environments displayed larger variation in community structures than others. For example, communities inhabiting englacial ice were the most similar (wUF: $0.47 \pm 0.15$; mean \pm s.d). In contrast, perennial cave ice samples from a single location (Itcus et al., 2018) harbored the widest range of microbial communities (wUf: $0.81 \pm 0.14$ ). $\beta$-diversity of permafrost microbiomes were more intermediate: relatively tight clustering was observed in permafrost from the

Storflaket peat bog (northern Sweden) with wider variation in samples of permafrost from University Valley (Antarctica) (Goordial et al., 2016; Monteux et al., 2018). The microbial communities within the Taylor Glacier's banded and solid basal ice facies clustered closely with the Sweden permafrost samples, while those within the clean basal ice and

Matanuska's dispersed basal ice were most similar to those observed in englacial ice from the NEEM ice core in Greenland (Miteva et al., 2015, 2016)(Figure 3).

We used an RDA model to determine how microbial lineages were distributed across the different types of frozen environments (Figure 4, left). The final RDA model explained $24.9 \%$ of the variability between samples and effectively separated the samples into three clusters, like that seen in Figure 3. Of the 89 microbial lineages included in this analysis, we identified 14 had loading vectors greater than the equilibrium contributionthe proportion of variance which would be explained by a random constrained axisindicating they were differentially abundant across the five types of frozen environments. Scalar projections of these lineages onto the centroid factor of each type of frozen environment allowed us to estimate how strongly these lineages were associated with each 
422 environment (Figure 4, right). As one would expect, supraglacial ice environments

423 harbored comparatively higher proportions of Cyanobacteria and plastid-related taxa than

424 the other frozen environments. Englacial ice environments were instead enriched with

425 members of the Pseudomonas, Janthinobacterium, Methylobacterium, and Oxalobacteraceae.

426 In contrast, basal ice, permafrost, and perennial cave ice environments all contained higher

427 populations Firmicutes related lineages: Clostridium, Ruminococcaceae, Desulfosporosinus,

428 and Paenibacillus.

430 4. DISCUSSION

\section{$431 \quad 4.1$ Microbial communities vary in size and composition across basal ice types}

Of the four different types of basal ice analyzed in this study, we found that those

433 containing large quantities of sediment or debris contained more extractable nucleic acids,

434 consistent with higher microbial abundances than those containing little or no subglacial

435 sediments. This is consistent with previous microscopic investigations of the GISP2 ice core

436 that found higher cell concentrations in deeper sections of the core where clay particles

437 were embedded in the ice (Tung et al., 2006). In addition to higher numbers of cells and

438 biomass, microbial diversity was also notably higher in the sediment-rich basal ice facies

439 relative to clean basal ice or englacial ice, indicating that subglacial debris is the primary

440 source of microorganisms in the basal ice.

441 Our estimates of bacterial cell abundance based on extracted DNA yields $\left(\sim 10^{6}\right.$ cells

$442 \mathrm{~g}^{-1}$ ice) were approximately 100-fold higher than those based on direct microscopic counts

$443\left(\sim 10^{4}\right.$ cells $\mathrm{g}^{-1}$ ice $)$, but only in the sediment-rich banded and solid basal ice. In the clean 
444 basal ice, these estimates were comparable. This suggests that Taylor Glacier's debris-rich 445 basal ice may contain significant amounts of microbial necromass.

447 Glacier contain high abundances of Firmicutes and Actinobacteria relative to the other

448 frozen habitats examined. Bacteria within these two phyla have been commonly observed

449 as the dominant taxa in a wide-range of frozen environments such as ground ice,

450 permafrost, polar saline springs, cryopegs, and sea ice (Kochkina et al., 2001; Steven et al.,

451 2007, 2008; Perreault et al., 2008; Lacelle et al., 2011; Boetius et al., 2015; Spirina et al.,

452 2017). One explanation for these observations is that the physiochemical stresses faced by

453 cells under frozen conditions (Doyle et al., 2012) favor the prevalence of microorganisms

454 that can form highly resistant endospores (Firmicutes) or spores (Actinobacteria). Although

455 this is consistent with the notion that extreme environmental conditions select for

456 microbial lineages with robust survival strategies (Filippidou et al., 2016), multiple lines of

457 evidence indicate this hypothesis does not adequately explain the abundance of these taxa

458 in our basal ice samples. First, ASVs related to known endospore-forming genera such as

459 Paenisporosarcina, Virgibacillus, Clostridium, and Desulfosporosinus were abundant in all

460 our RNA libraries. Because the rRNA content of endospores decreases relatively quickly

461 after sporulation-on the order of days to weeks (Segev et al., 2012; Korza et al., 2016)—

462 their detection in $\geq 10,000$ year-old basal ice strongly implies these taxa existed as

463 vegetative cells within the ice. Second, we found cultured isolates of Paenisporosarcina sp.

464 recovered directly from Taylor Glacier banded ice would not sporulate after being refrozen

465 in basal meltwater at in situ temperatures $\left(-15^{\circ} \mathrm{C}\right)$, but instead continuously incorporate

466 radiolabeled substrates into macromolecules (Doyle et al., 2013). Third, these isolates were 
467 heat-killed if the banded basal ice meltwater was pasteurized prior to cultivation

468 experiments, indicating we were not recovering these isolates from ancient endospores.

469 Finally, these findings are consistent with recent a study that performed 16S rRNA gene

470 sequencing of ancient permafrost samples after endospore enrichment and selective

471 depletion of DNA from dead cells and found many bacteria capable of forming endospores,

472 especially members of the Clostridia, were in a nondormant state (Burkert et al., 2019).

473 Collectively, these results suggest the high abundances of Firmicutes and Actinobacteria in

474 Taylor Glacier's basal ice is because they had the ability to remain active while frozen as

475 opposed to simply enduring in a durable, yet dormant state.

4.2 Young and warm versus old and cold basal ice

Due to the chemical lability of RNA, paired RNA/DNA 16S rRNA amplicon libraries

478 are a useful tool for discerning live organisms in a microbial community from those that are

479 long-dead or dormant. One should note there are limitations to this analysis and these

480 ratios are more reliable indicators of potential activity rather than real-time activity

481 (Blazewicz et al., 2013).

On average, only about $2 \%$ of the total ASVs in each sample were also detected in

483 the paired RNA library. This low proportion of potentially active ASVs suggests only a small

484 fraction of the microorganisms entrained into basal ice are suited to remain metabolically

485 active inside ice. Despite this small fraction, a pattern does emerge: the dispersed basal ice

486 from Matanuska Glacier contained a much larger population of potentially active ASVs than

487 any of the basal ice cryofacies recovered from Taylor Glacier.

489 geology and age of basal ice between these two glaciers. Assuming a non-zero rate of 
490 microbial attrition over time in ice due to, for example, the accumulation of cellular damage

491 or the depletion of resources, older ice would be expected to harbor smaller populations of

492 potentially active microorganisms than younger ice. Analysis of the $\delta \mathrm{D}$ and $\delta^{18} 0$

493 composition of meltwater from Taylor Glacier surface ice samples estimated they are

494 between 11,500 and 65,000 years old (Aciego et al., 2007), while more recent radiometric

$495{ }^{81} \mathrm{Kr}$ dating efforts near the glacial terminus expanded this estimate to nearly 123,500

496 years old (Buizert et al., 2014). In comparison, measurements of oxygen isotopes in

497 Matanuska Glacier's dispersed basal ice layer indicated the basal ice originated in the

498 accumulation area (Lawson and Kulla, 1978). Based on the velocity of Matanuska Glacier

$499\left(\sim 110 \mathrm{~m} \mathrm{yr}^{-1}\right)$, this would represent an approximate time of 250 years between deposition

500 and terminal ablation. Trace amounts of anthropogenic tritium produced by atmospheric

501 thermonuclear weapon tests in the 1950s and 1960s have also been detected in Matanuska

502 Glacier's basal ice zone (Strasser et al., 1996), indicating portions of this ice were formed

503 even more recently by subglacial freeze-on of surface-derived meltwater (Lawson, 1979).

504 Taken together, this indicates the dispersed ice we sampled from Matanuska is

505 substantially younger than any of the basal ice types we collected from Taylor Glacier.

507 and cold-based glacier should also affect the potential for metabolic activity in basal ice

508 environments. Taylor Glacier is primarily a cold-based glacier with a measured basal ice

509 temperature of $-15^{\circ} \mathrm{C}$ (Montross et al., 2014). In contrast, Matanuska Glacier is a temperate

510 glacier with a basal ice zone temperature just below $0^{\circ} \mathrm{C}$ (Lawson et al., 1998). As such,

511 cells frozen in Taylor Glacier's basal ice are under considerably higher physiochemical

512 stress than ice near the melting point. For example, the predicted ionic strength of the 
513 briny liquid at ice crystal boundaries - where the microorganisms also exist - is nearly

$5144.6 \mathrm{M}$ at $-15^{\circ} \mathrm{C}$. Comparatively, this is 11.5 -fold higher than the unfrozen water in ice at $-1^{\circ} \mathrm{C}$

515 (Doyle et al., 2012). Hence, the wider diversity and increased number of ASVs with a high

516 potential for metabolic activity in the dispersed basal ice may reflect the more favorable

517 conditions for metabolism in temperate versus cold-based glacial ice.

$518 \quad 4.3$ Debris-rich basal ice types are hot spots for microbial activity

Previous analyses of the gasses entrapped within Taylor Glacier banded basal ice

520 found that that $\mathrm{O}_{2}$ was depleted to as low as $4 \%$ in horizons where $\mathrm{CO}_{2}$ concentrations

521 were concurrently enriched as high as 20,000-fold relative to atmospheric concentrations

522 (Montross et al., 2014). Isotopic analyses of $\delta^{13} \mathrm{C}-\mathrm{CO}_{2}$ revealed this $\mathrm{CO}_{2}$ is isotopically

523 depleted (-24\%o), and therefore, was likely produced by in situ microbial respiration of

524 organic matter (Montross, 2012). This data supports our RNA-based 16S rRNA analyses,

525 which found the largest read counts and number of potentially active ASVs in the same

526 banded basal ice samples. Together, these observations strongly suggest Taylor Glacier's

527 banded basal ice horizons harbor metabolically active microbiomes that are altering the ice

528 gas chemistry at temperature of $-15^{\circ} \mathrm{C}$.

529 We also observed an enrichment of anaerobic taxa (e.g. Clostridia) within the same

530 banded basal ice samples where $\mathrm{O}_{2}$ concentrations were depleted. This raises the intriguing

531 possibility that, given sufficient time, the microbiomes of debris-rich basal ice may shift to

532 members with anoxic and anaerobic metabolisms (e.g. methanogenesis). In support of this,

533 multiple investigations have found large excesses of $\mathrm{CH}_{4}$ in debris-rich basal ice samples

534 from Greenland and Antarctica (Tung et al., 2006; Stibal et al., 2012; Wadham et al., 2012;

535 Rhodes et al., 2013; Lamarche-Gagnon et al., 2019; Lee et al., 2020). This hypothesis is also 
536 supported by a recent laboratory experiment that suggests cryoconite hole meltwater will

537 become enriched with anaerobic taxa after it is transported to a subglacial environment

538 (Zdanowski et al., 2017). However, it should be noted that this study was not performed in 539 ice.

$540 \quad$ Previous chemical analysis of Taylor Glacier's basal ice revealed dissolved organic

541 carbon (DOC) concentrations are much higher in the debris-rich basal ice types $\left(\sim 63 \mathrm{mg} \mathrm{L}^{-}\right.$

542 1) than in the debris-poor types $\left(\sim 0.8 \mathrm{mg} \mathrm{L}^{-1}\right)($ Montross, 2012; Montross et al., 2014). This

543 is also consistent with our microbiological results. Increased microbial activity in debris-

544 rich basal ice horizons may simply be a consequence of there being more substrates

545 available to consume. However, our investigation of multiple basal ice types indicates there

546 are likely additional, unidentified factors besides sediment content controlling whether

547 basal ice harbors an active microbiome. For example, although the banded and solid basal

548 ice samples harbored very similar microbial communities in our DNA-based libraries, we

549 found very little evidence for active ASVs within the solid basal ice. This suggests—at least

550 in polar glaciers containing basal ice horizons well below $0^{\circ} \mathrm{C}$ - the presence of debris

551 and/or DOC alone is not sufficient to support a metabolically active microbiome.

552 4.4. Phylogenetically similar communities in debris-rich basal ice and permafrost

553 Our meta-analysis indicates that that microbial communities within the banded and

554 solid basal ice from Taylor Glacier were phylogenetically most like those in permafrost and

555 were more distantly related to those in englacial ices and supraglacial ecosystems. This

556 suggests the ecophysiological stresses experienced by cells frozen in permafrost and basal

557 ice of a cold-based glacier are comparable and select for similar taxa. Both subsurface

558 environments contain high mineral debris and may remain frozen for many thousands of 
559 years. In fact, there is debate on whether the physical differences between cold, debris-rich

560 basal ice and permafrost are only terminological (Dobinski, 2006; Dąbski, 2019). Our

561 results support this contention, adding a microbiological dimension that provides

562 additional evidence for the parallels between these cryospheric environments. New data

563 from other cold-based glaciers and regions are needed to test if these similarities in

564 microbial composition with permafrost are robust across multiple locales. If so, permafrost

565 environments may be a useful analog for gaining valuable insight into the microbiology of

566 unexplored basal ice environments which are logistically more difficult to access.

$567 \quad 4.5$ Meta-analysis limitations

568 Comparing $16 \mathrm{~S}$ amplicon datasets from different studies is often hindered by

569 inconsistencies in sequencing platform used and which variable region of the 16S rRNA

570 gene was amplified. Using SEPP to insert heterogeneous ASVs from different studies into

571 the same reference tree creates stable phylogenetic placements, enabling integration and

572 meta-analysis of amplicon data from multiple variable regions of the 16S rRNA gene

573 (Janssen et al., 2018). Despite this, it is important to note the limitations of this approach.

574 First, integrating previously published 16S rRNA amplicon datasets based on Sanger

575 sequencing of clone libraries or DGGE profiling remains difficult as these older approaches

576 lack the read depth or taxonomic resolution to make meaningful comparisons with those

577 datasets prepared with more modern approaches. As a result, our meta-analysis

578 unfortunately excluded many early works which investigated the microbial ecology of

579 glacial ice using these approaches. Second, there are some potential biases in our meta-

580 analysis due to low coverage: despite growing interest in the microbial ecology of the

581 cryosphere, high-throughput surveys of permanently frozen ecosystems are still 
uncommon. For example, the Matanuska dispersed basal ice most resembled englacial ice samples in our meta-analysis. However, many of the englacial ice samples in the meta-

584 analysis are also from Matanuska Glacier. Indeed, there are exceedingly few microbiome

585 analyses of true englacial ice samples unaffected by either supraglacial or subglacial

586 processes, largely due to both the logistical difficulty of accessing and sampling these

587 environments.

\subsection{Conclusions and Implications}

590 frozen and, coupled with other biogeochemical data (Doyle et al., 2013; Montross et al.,

591 2014), indicate that some sediment-rich basal ice horizons host active microbial

592 communities that participate in biogeochemical cycling. Although we have limited

593 observations, our data further implies that a larger diversity of bacteria may remain

594 metabolically active in the relatively warm basal ice found beneath temperate glaciers and

595 ice sheet interiors (Lawson et al., 1998; Bell et al., 2011). Indeed, since the basal

596 temperature of the Antarctic and Greenland ice sheets are near or at the pressure-melting

597 point (Gow et al., 1968), this raises the intriguing possibility that these regions of the

598 cryosphere are more biogeochemically active than previously thought. We also found that

599 microorganisms in the basal ice of cold-based glaciers may be important biogeochemical

600 actors as well. Although rates of microbial activity in these environments are certainly

601 slower than those of warmer environments (Christner, 2002; Panikov et al., 2006; Amato et

602 al., 2009, 2010; Doyle et al., 2013), this may be offset by the long residence time of most

603 basal ice environments, providing ample time for biogeochemical processing. As climate

604 change continues to shrink the cryosphere and warm more basal ice environments, this 
605

606

607

608

609

610

611

612

613

614

615

616

617

618

619

620

621

622

623

624

625

626

627

628

629

630

631

632

633

634

635

636

637

638

639

may be an important consideration for high latitude land- and marine-based coastal

environments that receive regular discharges of meltwater derived from ancient basal ice horizons, an important source of dissolved organic carbon, nutrients, and trace metals

(Rignot and Jacobs, 2002; Jung et al., 2019; Vick-Majors et al., 2020).

\section{ACKNOWLEDGEMENTS}

This study was funded by a Division of Polar Programs grant (ANT-0636828) from the National Science Foundation.

\section{REFERENCES}

Aciego, S.M., Cuffey, K.M., Kavanaugh, J.L., Morse, D.L., and Severinghaus, J.P. (2007) Pleistocene ice and paleo-strain rates at Taylor Glacier, Antarctica. Quaternary Research 68: 303-313.

Amato, P. and Christner, B.C. (2009) Energy Metabolism Response to Low-Temperature and Frozen Conditions in Psychrobacter cryohalolentis. Applied and Environmental Microbiology 75: 711-718.

Amato, P., Doyle, S., and Christner, B.C. (2009) Macromolecular synthesis by yeasts under frozen conditions. Environmental Microbiology 11: 589-596.

Amato, P., Doyle, S.M., Battista, J.R., and Christner, B.C. (2010) Implications of Subzero Metabolic Activity on Long-Term Microbial Survival in Terrestrial and Extraterrestrial Permafrost. Astrobiology 10: 789-798.

Barker, J.D., Grottoli, A.G., and Lyons, W.B. (2018) Stable isotope evidence for the biogeochemical transformation of ancient organic matter beneath Suess Glacier, Antarctica. Arctic, Antarctic, and Alpine Research 50: e1448643.

Batjes, N.H. (2014) Total carbon and nitrogen in the soils of the world. European Journal of Soil Science 65: 10-21.

Bell, R.E., Ferraccioli, F., Creyts, T.T., Braaten, D., Corr, H., Das, I., et al. (2011) Widespread Persistent Thickening of the East Antarctic Ice Sheet by Freezing from the Base. Science 331: 1592-1595.

Bhatia, M.P., Das, S.B., Xu, L., Charette, M.A., Wadham, J.L., and Kujawinski, E.B. (2013) Organic carbon export from the Greenland ice sheet. Geochimica et Cosmochimica Acta 109: 329-344.

Blazewicz, S.J., Barnard, R.L., Daly, R.A., and Firestone, M.K. (2013) Evaluating rRNA as an indicator of microbial activity in environmental communities: limitations and uses. The ISME Journal 7: 2061-2068. 
Boetius, A., Anesio, A.M., Deming, J.W., Mikucki, J.A., and Rapp, J.Z. (2015) Microbial ecology of the cryosphere: sea ice and glacial habitats. Nature Reviews Microbiology 13: 677690.

Boyd, E.S., Skidmore, M., Mitchell, A.C., Bakermans, C., and Peters, J.W. (2010) Methanogenesis in subglacial sediments: Subglacial methanogenesis. Environmental Microbiology Reports 2: 685-692.

Buford Price, P., Jeffrey Morris, J., Bay, R.C., Adhikari, A., Giovannoni, S.J., and Vergin, K.L. (2015) Molecular Fossils from Microorganisms Preserved in Glacial Ice. bioRxiv.

Buizert, C., Baggenstos, D., Jiang, W., Purtschert, R., Petrenko, V.V., Lu, Z.-T., et al. (2014) Radiometric $81 \mathrm{Kr}$ dating identifies 120,000-year-old ice at Taylor Glacier, Antarctica. Proceedings of the National Academy of Sciences 111: 6876-6881.

Burkert, A., Douglas, T.A., Waldrop, M.P., and Mackelprang, R. (2019) Changes in the Active, Dead, and Dormant Microbial Community Structure across a Pleistocene Permafrost Chronosequence. Appl Environ Microbiol 85: e02646-18.

Callahan, B.J., McMurdie, P.J., Rosen, M.J., Han, A.W., Johnson, A.J.A., and Holmes, S.P. (2016) DADA2: High-resolution sample inference from Illumina amplicon data. Nature Methods 13: 581-583.

Caporaso, J.G., Lauber, C.L., Walters, W.A., Berg-Lyons, D., Huntley, J., Fierer, N., et al. (2012) Ultra-high-throughput microbial community analysis on the Illumina HiSeq and MiSeq platforms. The ISME journal 6: 1621-1624.

Christner, B.C. (2002) Incorporation of DNA and Protein Precursors into Macromolecules by Bacteria at -15oC. Applied and Environmental Microbiology 68: 6435-6438.

Christner, B.C., Mikucki, J.A., Foreman, C.M., Denson, J., and Priscu, J.C. (2005) Glacial ice cores: A model system for developing extraterrestrial decontamination protocols. Icarus 174: 572-584.

Dąbski, M. (2019) Should Glaciers Be Considered Permafrost? Geosciences 9: 517.

Dieser, M., Broemsen, E.L.J.E., Cameron, K.A., King, G.M., Achberger, A., Choquette, K., et al. (2014) Molecular and biogeochemical evidence for methane cycling beneath the western margin of the Greenland Ice Sheet. The ISME Journal 8: 2305-2316.

Dobinski, W. (2006) Ice and environment: A terminological discussion. Earth-Science Reviews 79: 229-240.

Doyle, S., Dieser, M., Broemsen, E., and Christner, B. (2012) General characteristics of coldadapted microorganisms. In Polar Microbiology: Life in a Deep Freeze. American Society of Microbiology, pp. 103-125.

Doyle, S., Montross, S., Skidmore, M., and Christner, B. (2013) Characterizing Microbial Diversity and the Potential for Metabolic Function at $-15^{\circ} \mathrm{C}$ in the Basal Ice of Taylor Glacier, Antarctica. Biology 2: 1034-1053.

Filippidou, S., Wunderlin, T., Junier, T., Jeanneret, N., Dorador, C., Molina, V., et al. (2016) A Combination of Extreme Environmental Conditions Favor the Prevalence of Endospore-Forming Firmicutes. Front Microbiol 7:.

Goordial, J., Davila, A., Lacelle, D., Pollard, W., Marinova, M.M., Greer, C.W., et al. (2016) Nearing the cold-arid limits of microbial life in permafrost of an upper dry valley, Antarctica. The ISME Journal 10: 1613-1624.

Gow, A.J., Ueda, H.T., and Garfield, D.E. (1968) Antarctic Ice Sheet: Preliminary Results of First Core Hole to Bedrock. Science 161: 1011-1013. 
Hood, E., Fellman, J., Spencer, R.G.M., Hernes, P.J., Edwards, R., D’Amore, D., and Scott, D. (2009) Glaciers as a source of ancient and labile organic matter to the marine environment. Nature 462: 1044-1047.

Hopwood, M.J., Carroll, D., Dunse, T., Hodson, A., Holding, J.M., Iriarte, J.L., et al. (2019) Review Article: How does glacier discharge affect marine biogeochemistry and primary production in the Arctic? The Cryosphere Discussions 1-51.

Hubbard, B., Cook, S., and Coulson, H. (2009) Basal ice facies: a review and unifying approach. Quaternary Science Reviews 28: 1956-1969.

Itcus, C., Pascu, M.D., Lavin, P., Perşoiu, A., Iancu, L., and Purcarea, C. (2018) Bacterial and archaeal community structures in perennial cave ice. Sci Rep 8:.

Janssen, S., McDonald, D., Gonzalez, A., Navas-Molina, J.A., Jiang, L., Xu, Z.Z., et al. (2018) Phylogenetic Placement of Exact Amplicon Sequences Improves Associations with Clinical Information. mSystems 3: e00021-18.

Jung, J., Yoo, K.-C., Rosenheim, B.E., Conway, T.M., Lee, J.I., Yoon, H.I., et al. (2019) Microbial Fe(III) reduction as a potential iron source from Holocene sediments beneath Larsen Ice Shelf. Nat Commun 10: 1-10.

Knight, P.G. (1997) The basal ice layer of glaciers and ice sheets. Quaternary Science Reviews 16: 975-993.

Kochkina, G., Ivanushkina, N., Karasev, S., Gavrish, E.Y., Gurina, L., Evtushenko, L., et al. (2001) Survival of micromycetes and actinobacteria under conditions of long-term natural cryopreservation. Microbiology 70: 356-364.

Korza, G., Setlow, B., Rao, L., Li, Q., and Setlow, P. (2016) Changes in Bacillus Spore Small Molecules, rRNA, Germination, and Outgrowth after Extended Sublethal Exposure to Various Temperatures: Evidence that Protein Synthesis Is Not Essential for Spore Germination. J Bacteriol 198: 3254-3264.

Lacelle, D., Radtke, K., Clark, I.D., Fisher, D., Lauriol, B., Utting, N., and Whyte, L.G. (2011) Geomicrobiology and occluded 02-CO2-Ar gas analyses provide evidence of microbial respiration in ancient terrestrial ground ice. Earth and Planetary Science Letters 306: 46-54.

Lamarche-Gagnon, G., Wadham, J.L., Sherwood Lollar, B., Arndt, S., Fietzek, P., Beaton, A.D., et al. (2019) Greenland melt drives continuous export of methane from the ice-sheet bed. Nature 565: 73-77.

Lawson, D. (1979) Sedimentological Analysis of the Western Terminus Region of the Matanuska Glacier, Alaska. 132.

Lawson, D.E. and Kulla, J.B. (1978) An Oxygen Isotope Investigation of the Origin of the Basal Zone of the Matanuska Glacier, Alaska. The Journal of Geology 86: 673-685.

Lawson, D.E., Strasser, J.C., Evenson, E.B., Alley, R.B., Larson, G.J., and Arcone, S.A. (1998) Glaciohydraulic supercooling: a freeze-on mechanism to create stratified, debrisrich basal ice: I. Field evidence. Journal of Glaciology 44: 547-562.

Lee, J.E., Edwards, J.S., Schmitt, J., Fischer, H., Bock, M., and Brook, E.J. (2020) Excess methane in Greenland ice cores associated with high dust concentrations. Geochimica et Cosmochimica Acta 270: 409-430.

McDonald, D., Price, M.N., Goodrich, J., Nawrocki, E.P., DeSantis, T.Z., Probst, A., et al. (2012) An improved Greengenes taxonomy with explicit ranks for ecological and evolutionary analyses of bacteria and archaea. The ISME journal 6: 610. 
Michaud, A.B., Dore, J.E., Achberger, A.M., Christner, B.C., Mitchell, A.C., Skidmore, M.L., et al. (2017) Microbial oxidation as a methane sink beneath the West Antarctic Ice Sheet. Nature Geoscience 10: 582-586.

Mirarab, S., Nguyen, N., and Warnow, T. (2012) SEPP: SATé-enabled phylogenetic placement. In Biocomputing 2012. World Scientific, pp. 247-258.

Miteva, V., Rinehold, K., Sowers, T., Sebastian, A., and Brenchley, J. (2015) Abundance, viability and diversity of the indigenous microbial populations at different depths of the NEEM Greenland ice core. Polar Research 34: 25057.

Miteva, V., Sowers, T., Schüpbach, S., Fischer, H., and Brenchley, J. (2016) Geochemical and Microbiological Studies of Nitrous Oxide Variations within the New NEEM Greenland Ice Core during the Last Glacial Period. Geomicrobiology Journal 33: 647660.

Miteva, V.I., Sheridan, P.P., and Brenchley, J.E. (2004) Phylogenetic and Physiological Diversity of Microorganisms Isolated from a Deep Greenland Glacier Ice Core. Applied and Environmental Microbiology 70: 202-213.

Monteux, S., Weedon, J.T., Blume-Werry, G., Gavazov, K., Jassey, V.E.J., Johansson, M., et al. (2018) Long-term in situ permafrost thaw effects on bacterial communities and potential aerobic respiration. The ISME Journal 12: 2129-2141.

Montross, S., Skidmore, M., Christner, B., Samyn, D., Tison, J.-L., Lorrain, R., et al. (2014) Debris-Rich Basal Ice as a Microbial Habitat, Taylor Glacier, Antarctica. Geomicrobiology Journal 31: 76-81.

Montross, S.N. (2012) Biogeochemistry of basal ice from Taylor Glacier, Antarctica, Montana State University.

Montross, S.N., Skidmore, M., Tranter, M., Kivimaki, A.-L., and Parkes, R.J. (2013) A microbial driver of chemical weathering in glaciated systems. Geology 41: 215-218.

Panikov, N.S., Flanagan, P.W., Oechel, W.C., Mastepanov, M.A., and Christensen, T.R. (2006) Microbial activity in soils frozen to below $-39^{\circ} \mathrm{C}$. Soil Biology and Biochemistry 38: 785-794.

Perreault, N.N., Greer, C.W., Andersen, D.T., Tille, S., Lacrampe-Couloume, G., Lollar, B.S., and Whyte, L.G. (2008) Heterotrophic and Autotrophic Microbial Populations in Cold Perennial Springs of the High Arctic. Appl Environ Microbiol 74: 6898-6907.

Priscu, J.C., Tulaczyk, S., Studinger, M., Kennicutt, M., Christner, B.C., and Foreman, C.M. (2008) Antarctic subglacial water: origin, evolution and ecology. Polar lakes and rivers: limnology of Arctic and Antarctic aquatic ecosystems Oxford University Press, Oxford 119-135.

Quast, C., Pruesse, E., Yilmaz, P., Gerken, J., Schweer, T., Yarza, P., et al. (2013) The SILVA ribosomal RNA gene database project: improved data processing and web-based tools. Nucleic Acids Research 41: D590-D596.

Rhodes, R.H., Faïn, X., Stowasser, C., Blunier, T., Chappellaz, J., McConnell, J.R., et al. (2013) Continuous methane measurements from a late Holocene Greenland ice core: Atmospheric and in-situ signals. Earth and Planetary Science Letters 368: 9-19.

Rignot, E. and Jacobs, S.S. (2002) Rapid Bottom Melting Widespread near Antarctic Ice Sheet Grounding Lines. Science 296: 2020-2023.

Salter, S.J., Cox, M.J., Turek, E.M., Calus, S.T., Cookson, W.O., Moffatt, M.F., et al. (2014) Reagent and laboratory contamination can critically impact sequence-based microbiome analyses. BMC biology 12: 87. 
Segev, E., Smith, Y., and Ben-Yehuda, S. (2012) RNA Dynamics in Aging Bacterial Spores. Cell 148: 139-149.

Sharp, M., Parkes, J., Cragg, B., Fairchild, I.J., Lamb, H., and Tranter, M. (1999) Widespread bacterial populations at glacier beds and their relationship to rock weathering and carbon cycling. Geology 27: 107.

Sheridan, P.P., Miteva, V.I., and Brenchley, J.E. (2003) Phylogenetic Analysis of Anaerobic Psychrophilic Enrichment Cultures Obtained from a Greenland Glacier Ice Core. Applied and Environmental Microbiology 69: 2153-2160.

Skidmore, M.L., Foght, J.M., and Sharp, M.J. (2000) Microbial Life beneath a High Arctic Glacier. Appl Environ Microbiol 66: 3214-3220.

Spirina, E., Durdenko, E., Demidov, N., Abramov, A., Romanovsky, V., and Rivkina, E. (2017) Halophilic-psychrotrophic bacteria of an Alaskan cryopeg-a model for astrobiology. Paleontological Journal 51: 1440-1452.

Steven, B., Briggs, G., McKay, C.P., Pollard, W.H., Greer, C.W., and Whyte, L.G. (2007) Characterization of the microbial diversity in a permafrost sample from the Canadian high Arctic using culture-dependent and culture-independent methods: Microbial diversity in Canadian high Arctic permafrost. FEMS Microbiology Ecology 59: 513-523.

Steven, B., Pollard, W.H., Greer, C.W., and Whyte, L.G. (2008) Microbial diversity and activity through a permafrost/ground ice core profile from the Canadian high Arctic. Environmental Microbiology 10: 3388-3403.

Stibal, M., Wadham, J.L., Lis, G.P., Telling, J., Pancost, R.D., Dubnick, A., et al. (2012) Methanogenic potential of Arctic and Antarctic subglacial environments with contrasting organic carbon sources. Global Change Biology 18: 3332-3345.

Strasser, J.C., Lawson, D.E., Larson, G.J., Evenson, E.B., and Alley, R.B. (1996) Preliminary results of tritium analyses in basal ice, Matanuska Glacier, Alaska, U.S.A.: evidence for subglacial ice accretion. Annals of Glaciology 22: 126-133.

Tranter, M., Sharp, M.J., Lamb, H.R., Brown, G.H., Hubbard, B.P., and Willis, I.C. (2002) Geochemical weathering at the bed of Haut Glacier d'Arolla, Switzerland?a new model. Hydrological Processes 16: 959-993.

Tranter, M., Skidmore, M., and Wadham, J. (2005) Hydrological controls on microbial communities in subglacial environments. Hydrological Processes 19: 995-998.

Tung, H. c., Price, P. b., Bramall, N. e., and Vrdoljak, G. (2006) Microorganisms Metabolizing on Clay Grains in 3-Km-Deep Greenland Basal Ice. Astrobiology 6: 69-86.

Vick-Majors, T.J., Michaud, A.B., Skidmore, M.L., Turetta, C., Barbante, C., Christner, B.C., et al. (2020) Biogeochemical Connectivity Between Freshwater Ecosystems beneath the West Antarctic Ice Sheet and the Sub-Ice Marine Environment. Global Biogeochemical Cycles 34: e2019GB006446.

Wadham, J.L., Arndt, S., Tulaczyk, S., Stibal, M., Tranter, M., Telling, J., et al. (2012) Potential methane reservoirs beneath Antarctica. Nature 488: 633-637.

Wadham, J.L., Bottrell, S., Tranter, M., and Raiswell, R. (2004) Stable isotope evidence for microbial sulphate reduction at the bed of a polythermal high Arctic glacier. Earth and Planetary Science Letters 219: 341-355.

Wadham, J.L., Tranter, M., Skidmore, M., Hodson, A.J., Priscu, J., Lyons, W.B., et al. (2010) Biogeochemical weathering under ice: Size matters: GLACIAL BIOGEOCHEMICAL WEATHERING. Global Biogeochemical Cycles 24: n/a-n/a. 
822 Wang, Q., Garrity, G.M., Tiedje, J.M., and Cole, J.R. (2007) Naïve Bayesian Classifier for Rapid Assignment of rRNA Sequences into the New Bacterial Taxonomy. Appl Environ

$824 \quad$ Microbiol 73: 5261-5267.

Yde, J.C., Finster, K.W., Raiswell, R., Steffensen, J.P., Heinemeier, J., Olsen, J., et al. (2010) Basal ice microbiology at the margin of the Greenland ice sheet. Annals of Glaciology 51: 71-79.

Yung, P.T., Shafaat, H.S., Connon, S.A., and Ponce, A. (2007) Quantification of viable endospores from a Greenland ice core: Quantification of viable endospores from a Greenland ice core. FEMS Microbiology Ecology 59: 300-306. (2017) Enrichment of Cryoconite Hole Anaerobes: Implications for the Subglacial Microbiome. Microb Ecol 73: 532-538.

834 



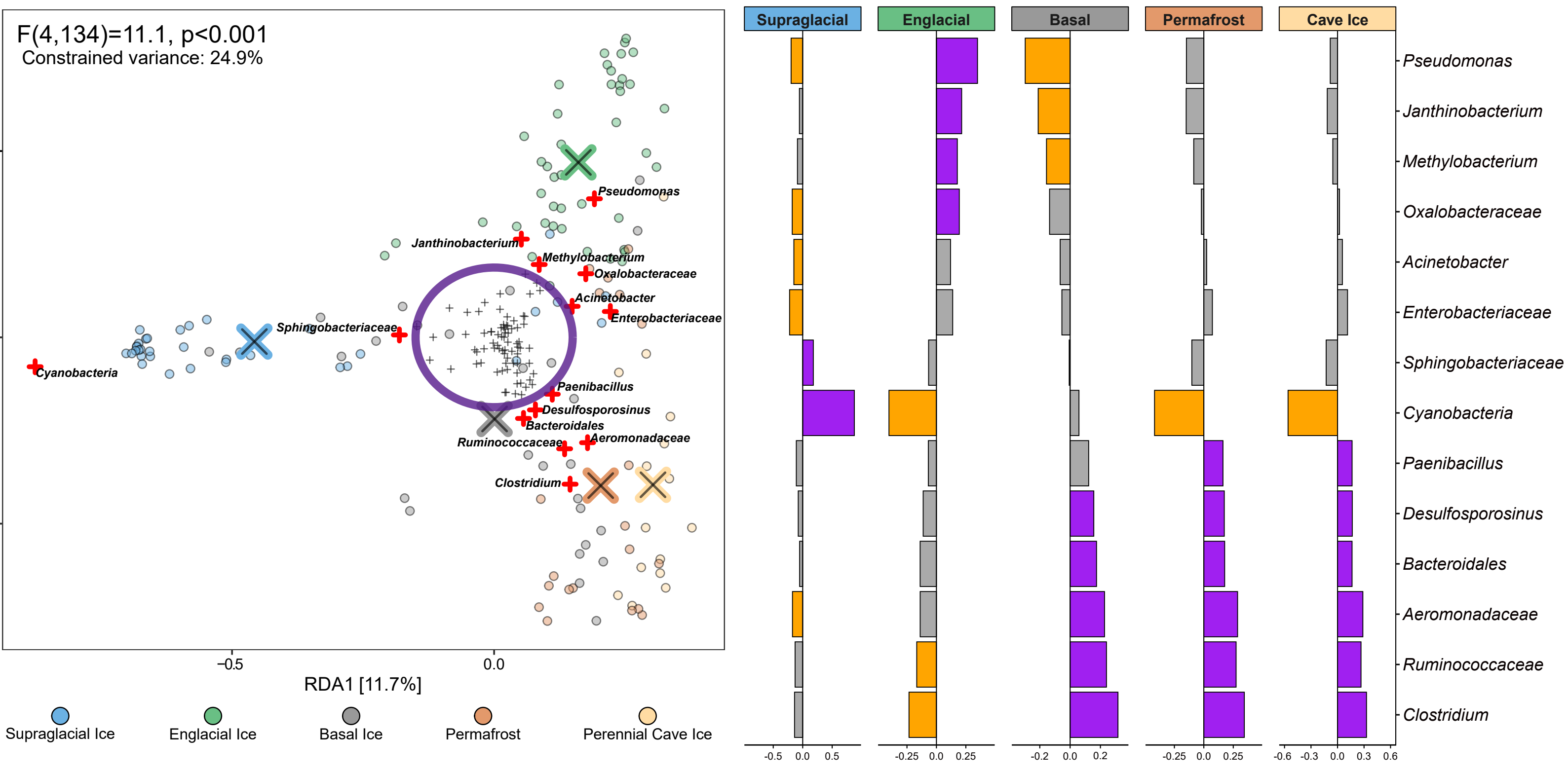

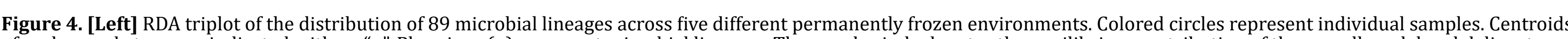

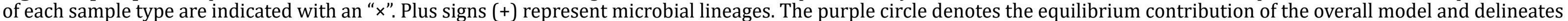

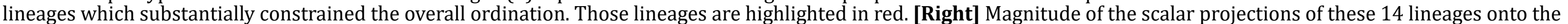

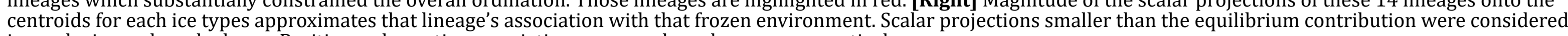
inconclusive and marked gray. Positive and negative associations are purple and orange, respectively. 

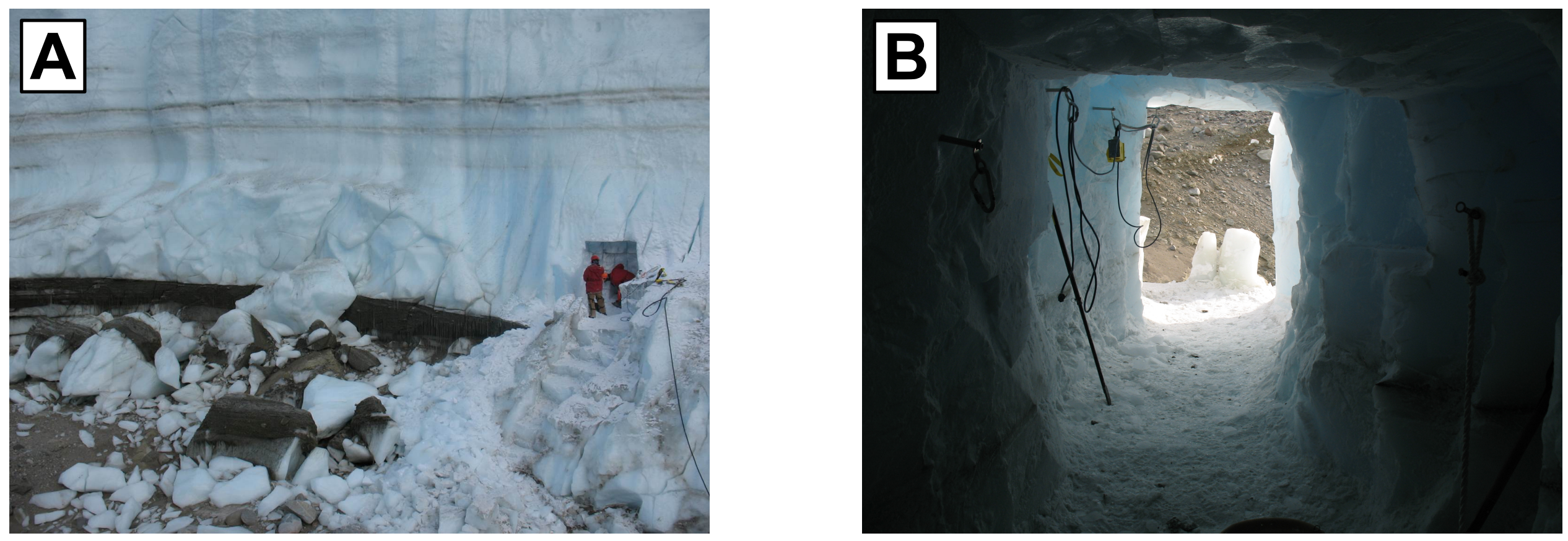

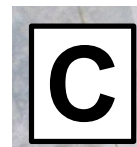

Figure S1. [A] A subglacial tunnel was excavated into the basal zone of Taylor Glacier's northern lateral margin. [B] View from inside one of the excavation tunnels. [C] During the 2007 expedition, a vertical shaft was excavated and stratigraphic sequence of multiple basal ice types was sampled. [D] During the 2009 expedition, a large chamber was excavated to sample a horizon of debris-rich banded basal ice. 


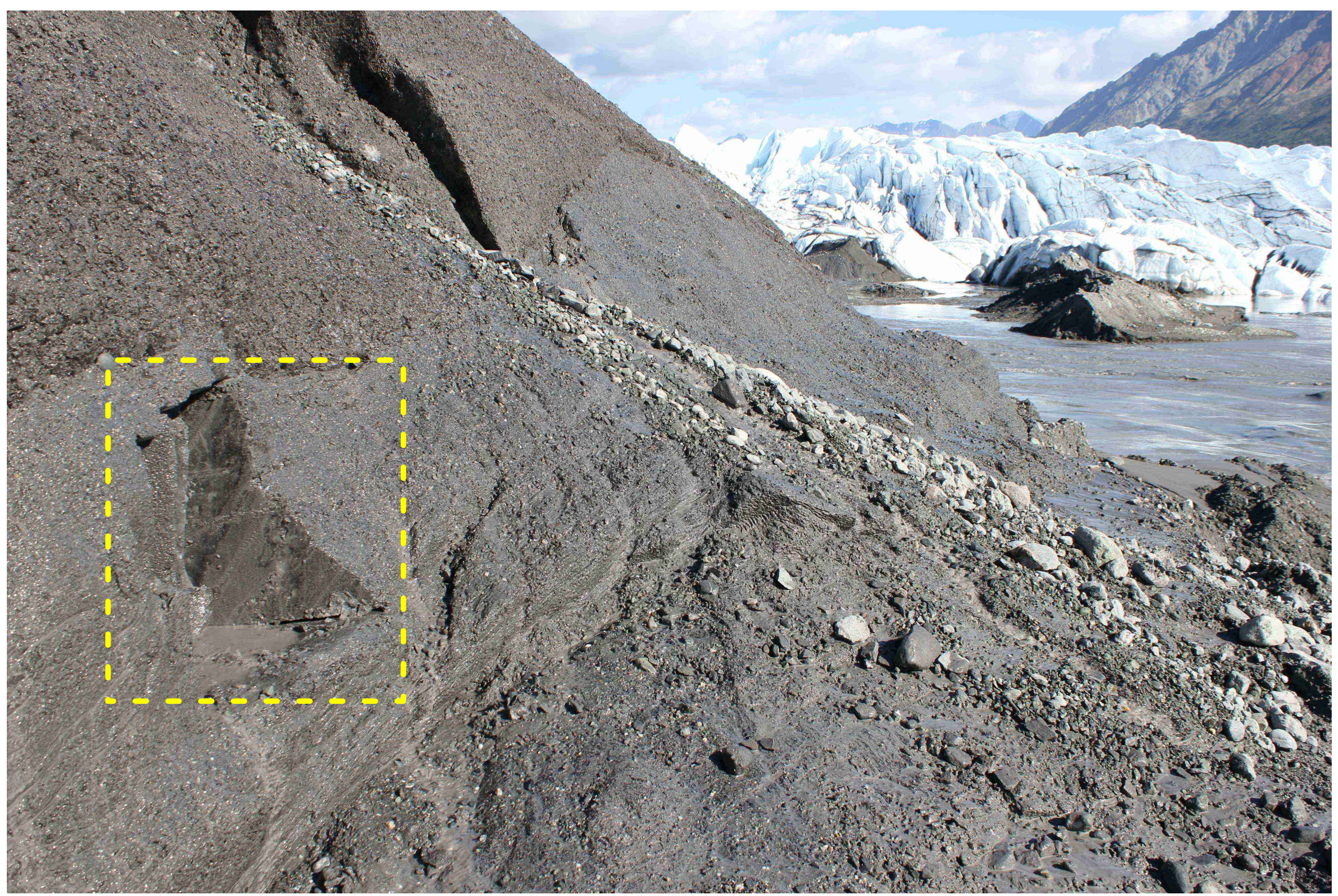

Figure S2. An exposed horizon debris-rich basal ice near the terminus of Matanuska Glacier, Alaska. The sampled area, collected using an electric chainsaw, is highlighted inside the yellow-box. 

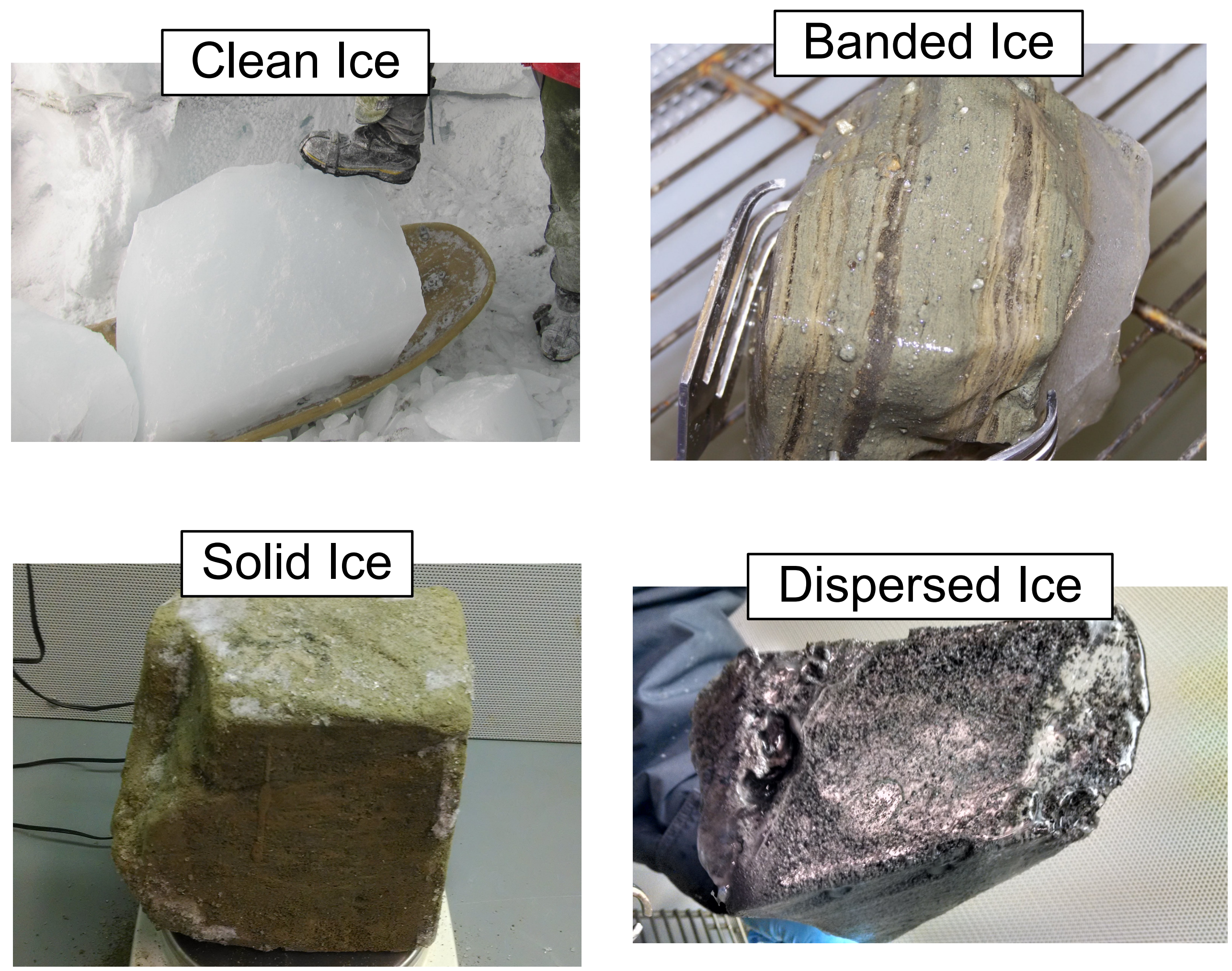

Figure S3. Examples of each type of basal ice analyzed in this study. Clean ice, banded ice, and solid ice were collected from Taylor Glacier, Antarctica. Dispersed ice was collected from Matanuska Glacier, Alaska. 